J. Clin. Chem. Clin. Biochem.

Vol. 14, 1976, pp. 213-215

\title{
Total Plasma Porphyrins in Renal Disease
}

\author{
By E. D. Ivanov and Elka Drenska
}

Institute of Nutrition-Centre of Hygiene at the Medical Academy, Sofia, Bulgaria

(Received November 26, 1974/March 14, 1975)

Summary: Thirty patients suffering from chronic kidney disease were examined for urinary, fecal and total plasma porphyrins. Twenty patients had nitrogen retention whereas the remaining ten patients displayed normal values. Urinary coproporphyrin excretion and total plasma porphyrin levels were comparatively less pronounced in patients with nitrogen retention. Such changes in porphyrin metabolism could be explained by a diminished capacity for kidney excretion. It is concluded that the total amount of porphyrins synthesized in the body is decreased as a result of nitrogen retention.

\section{Gesamt-Plasmaporphyrine bei Nierenkrankheiten}

Zusammenfassung: Die Harn-, Kot- und Plasmaporphyrine wurden bei 30 chronisch Nierenkranken (10 ohne und 20 mit Stickstoffretention) untersucht. Bei Kranken mit Stickstoffretention waren die Koproporphyrinausscheidung im Harn und die gesamten Plasmaporphyrine stärker erniedrigt. Diese Veränderungen im Porphyrinstoff wechsel sind eine Folge der beschränkten Ausscheidungskapazität der Nieren. Außerdem ist eine Verminderung der gesamten im Organismus synthetisierten Porphyrinmenge infolge der Stickstoffretention anzunehmen.

Although the kidneys play an important part in the elimination of porphyrins, studies on the mechanism of urinary porphyrin excretion (1-3) and the changes in porphyrin metabolism in renal disease $(1,4)$ are surprisingly few. The liver is also involved in the excretion of porphyrins, $2 / 3$ to $4 / 5$ of the total amount of porphyrins being excreted through the bile $(5,6)$. In abnormal conditions hepatic and renal porphyrin ratios of excretion undergo conspicuous changes. In obstructive jaundice fecal coproporphyrin is reduced whereas urinary coproporphyrin increases (6), but high plasma porphyrin levels were found in only a few patients with cholestasis (in preparation). A rise of plasma porphyrin has been demonstrated on experimental models in rabbits suffering from mechanical anuria with a concomitant obstructive jaundice. In either of these situations, taken separately, the plasma porphyrins were normal (in preparation).

\section{Materials and Methods}

\section{Patients}

Thirty patients with renal diseases (10 without and 20 with nitrogen retention) were included in the study. Twenty one patients had chronic pyelonephritis. In three of them the disorder was associated with diabetes mellitus. Five patients had chronic nephritis, three - chronic glomerulonephritis and 1 - endemic nephropathy. The ciagnosis and the stage of the disease were determined by means of numerous clinical, laboratory, biochemical, hematological and functional tests.

\section{Methods}

Plasma porphyrins were assayed by the procedure of Schlenker et al. (7), urinary uroporphyrin by that of Gutniak \& Dancewicz (8) and coproporphyrin by the Rimington technique (9). Stools: uroporphyrin was detected by a technique described by IVanov (10), coproporphyrin and protoporphyrin - after Rimington's technique (9). Blood urea and hemoglobin data determined the stage of the disease. The results were statistically processed at a significance level of $\mathrm{p} \geqq 0.05$.

\section{Results}

A list of all patients with the diagnosis and the results of laboratory procedures is shown on Table 1 and the stastistical processing - on Table 2.

Excretion of urinary coproporphyrin was substantially reduced in patients with renal disease, the decrease being more pronounced in patients with nitrogen retention. Urinary uroporphyrin was also low, being lower in patients with compensated renal disease. Fecal uro-, copro- and protoporphyrin excretion was normal in both groups of patients with renal disease. Plasma porphyrin levels were reduced, but there was no significant difference between patients with and without nitrogen reten- 
Tab. 1. Urinary, fecal and total plasma porphyrins in patients with renal disease

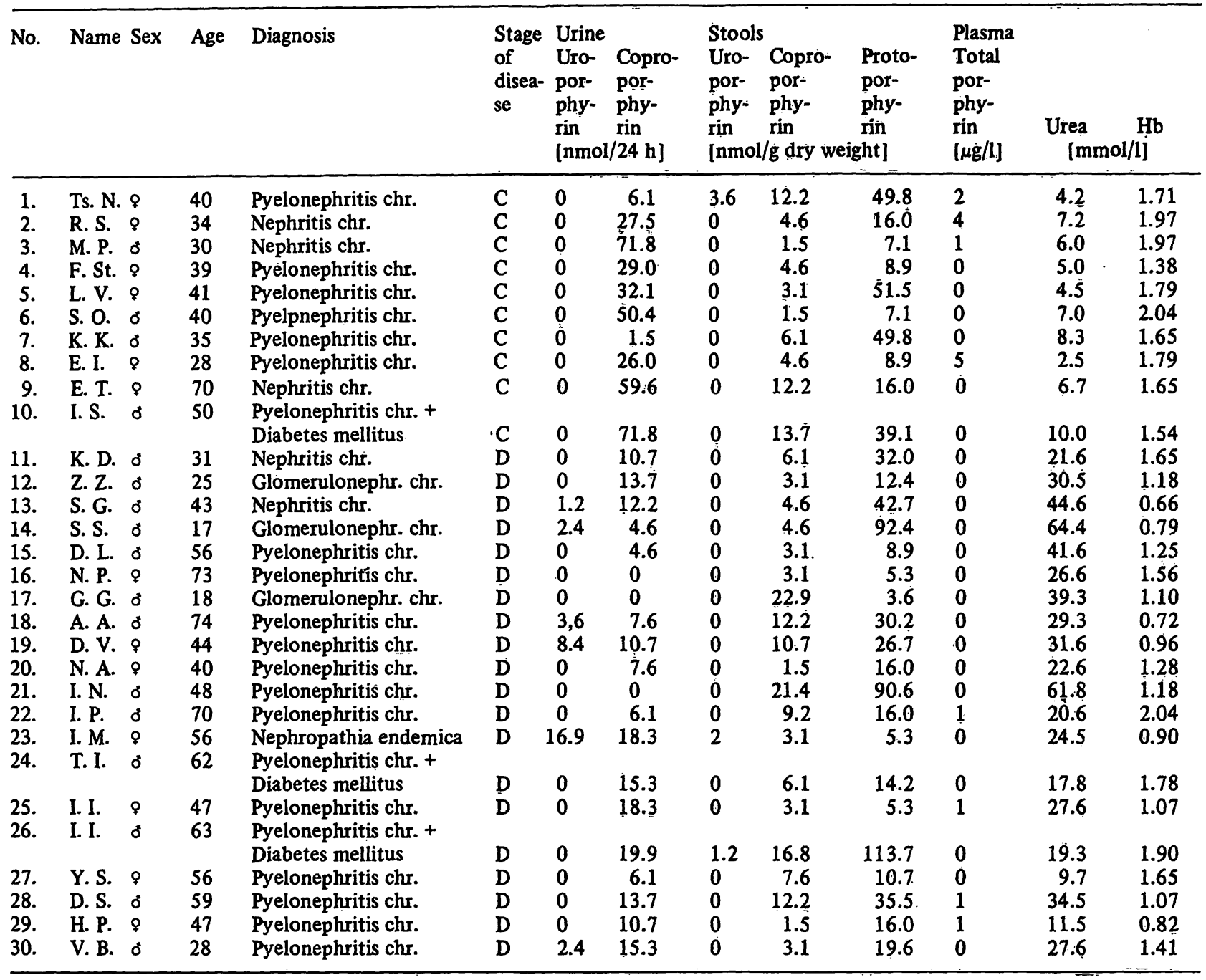

$C=$ compensated

$D=$ decompensated

Tab. 2. Statistical processing of the results of studies of the parameters of porphyrin metabolism in compensated and decompensated renal disease.

\begin{tabular}{|c|c|c|c|c|c|c|}
\hline Group & $\begin{array}{l}\text { Urine } \\
\text { Uro- } \\
\text { porphyrin } \\
\text { [nmol/24 h] }\end{array}$ & $\begin{array}{l}\text { Copro- } \\
\text { porphyrin }\end{array}$ & $\begin{array}{l}\text { Stool } \\
\text { Uro- } \\
\text { porphyrin } \\
\text { [nmol/g dry }\end{array}$ & $\begin{array}{l}\text { Copro- } \\
\text { porphyrin } \\
\text { weight] }\end{array}$ & $\begin{array}{l}\text { Proto- } \\
\text { porphyrin }\end{array}$ & $\begin{array}{l}\text { Plasma } \\
\text { Total } \\
\text { Porphyrin } \\
{[\mu \mathrm{g} / 1]}\end{array}$ \\
\hline $\begin{array}{l}\text { I. Control group of } \\
\text { normal men } \\
\text { and women } \\
n=20\end{array}$ & $\begin{array}{l}3.6 \pm 10.4 \\
\text { p I:II }<0.001\end{array}$ & $\begin{array}{l}82.5 \pm 33.6 \\
<0.001\end{array}$ & $\stackrel{0}{>0.05}$ & $\begin{array}{l}6.6 \pm 6.4 \\
\ldots>0.05\end{array}$ & $\begin{array}{l}34.5 \pm 17.8 \\
>0.05\end{array}$ & $\begin{array}{l}4 \pm 2 \\
<0.001\end{array}$ \\
\hline $\begin{array}{l}\text { II. Compensated } \\
\text { ienal disease } \\
n=10\end{array}$ & $\begin{array}{l}0 \\
\text { p II:III }<0.001\end{array}$ & $\begin{array}{l}37.6 \pm 24.4 \\
<0.01\end{array}$ & $\begin{array}{l}0.4 \pm 1.1 \\
>0.05\end{array}$ & $\begin{array}{l}6.4 \pm 4.6 \\
>0.05\end{array}$ & $\begin{array}{l}25.4 \pm 19.6 \\
>0.05\end{array}$ & $\begin{array}{l}1.2 \pm 2 \\
>0.05\end{array}$ \\
\hline $\begin{array}{l}\text { III. Decompensated } \\
\text { renal disease } \\
n=20\end{array}$ & $\begin{array}{l}1.8 \pm 4.2 \\
\text { p I:III }>0.05\end{array}$ & $\begin{array}{l}9.8 \pm 4.7 \\
<0.001\end{array}$ & $\begin{array}{l}0.2 \div 0.6 \\
>0.05\end{array}$ & $\begin{array}{l}7.8 \pm 6.4 \\
>0.05\end{array}$ & $\begin{array}{l}29.9 \pm 32.0 \\
>0.05\end{array}$ & $\begin{array}{l}0.2 \pm 0.4 \\
<0.001\end{array}$ \\
\hline
\end{tabular}

The results are expressed by $\bar{x} \pm S D$. 
tion. The type of changes depended upon the stage of the renal disease - whether it was compensated or not and not on the specific disease itself.

\section{Discussion}

In accordance with our earlier studies in patients with endemic nephropathy, chronic nephritis and pyelonephritis (4), a low urinary coproporphyrin excretion was found. Since coproporphyrin is excreted in the urine on the basis of threshold-free substances its excretion diminishes as early as the stage of compensation parallel to the initial impairment of renal function. Nitrogen retention leads to a further decrease in coproporphyrin excretion. All these phenomena suggest that these findings are due to a diminished excretory capacity of the kidneys. One may expect that plasma porphyrin is elevated during the stage of the decompensation of renal disease, although it contains more protoporphyrin than copropor- phyrin. Another possibility may be an increase in porphyrin excretion with the stools if the liver compensatorily undertakes the excretion of porphyrins normally excreted through the urine. Fecal porphyrins, however, were not increased in patients with renal disease. Plasma porphyrin values were reduced as well.

This laboratory constellation characterizing porphyrin metabolism in renal disease may result from the decrease in the total amount of synthesized porphyrins or possibly from a process of decreased degradation. Considering the frequent development of pronounced anemia in decompensated renal disease (,nephrogenic anemia") it may be assumed that the porphyrins synthesized in the bone marrow are in fact the reduced ones. Further studies on this problem are mandatory for the elucidation on the role of the disorders of porphyrin biosynthesis in the pathogenesis of porphyrin metabolism changes in renal disease.

\section{References}

1. Vanotti, A. (1937), Porphyrine und Porphyrinkrankheiten, Springer, Berlin.

2. Berman, J., Schück, O. \& Semrádova, M. (1958), Z. Gesamte Inn. Med. 13, 283-285.

3. Czitober, H., Denk, H. \& Schnack, H. (1972), Klin. Wochenschr. 48, 59-60.

4. Iwanow, E. (1968), Münch. Med. Wochenschr. 110, 1783 -1789 .

5. Brugsch, J. (1935), Z. Gesamte Exp. Med. 95, 471-481.

6. Brugsch, J. (1935), Z. Gesamte Exp. Med. 95, 493-507.

7. Schlenker, F., Davies, C. \& Kitchell, C. (1961), Amer. J. Clin. Pathol. 36, 31-36.

8. Gutniak, O. \& Dancewicz, A. (1958), Med. Pracy 9, 1-10.

9. Rimington, C. (1961), Assoc. Clin. Pathol. Broadsheet (N.S.) $36,1-7$.

10. Ivanov, E., Sovr. Med. (bulg.), in press.

Dr. Emil D. Ivanov

Institute of Nutrition-Centre of Hygiene 15, Dimiter Nestorov Street

Sofia 1431, Bulgaria 


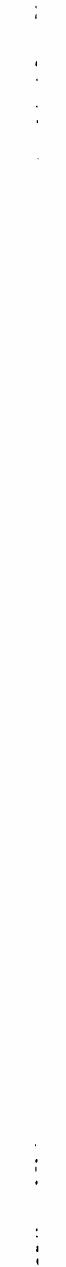

